of autoantibodies detected. Further clinical and experimental studies are required to determine the precise mechanisms concerned in the pathogenesis of these two disorders.

We wish to thank the physicians at the London, St. Bartholomew's, and the Southampton General Hospitals, in particular Dr. A. Dawson and Dr. J. Bamforth, for permission to study patients under their care; Mr. J. Corrigan for assistance with the ophthalmological investigations; Professor I. Doniach and Dr. A. Stansfield for reviewing the histological sections; and Dr. G. Franglen and Mr. R. Lloyd, for assistance with the immunological investigations.

The work was supported by funds from the Medical Research Council (A.M.S.M.), the London Hospital Free Funds (P.L.G.), and a grant from the Governors of St. Bartholomew's Hospital (R.B.).

Requests for reprints to Dr. P. L. Golding, Division of Medicine, the London Hospital, Whitechapel, London E.1.
REFERENCES

Bertram, U., and Halberg, P. (1965). Acta Allergologica, 20, 472

Bloch, K. J., Buchanan, W. W., Wohl, M. J., and Bernim, J. J. (1965) Medicine, 44, 187.

Chisholm, D. M., and Mason, D. K. (1968). Journal of Clinical Pathology, 21,656 .

Cristiansson, J. (1954). Acta Ophthalmologica, 32, 161.

Doniach, D., Roitt, I. M., Walker, J. G., and Sherlock, S. (1966). Clinical and Experimental Immunology, 1, 237.

Doniach, D., and Walker, J. G. (1969). Lancet, 1, 813.

Fox, R. A., James, D. G., Scheuer, P. J., Sharma, O., and Sherlock, S. 1969). Lancet, 1, 959.

Heaton, J. M. (1959). British Medical fournal, 1, 466.

Hobbs, J. R. (1970). British Fournal of Hospital Medicine, 3, 669.

Holm, S. (1949). Acta Ophthalmologica, Suppl. No. 33, p. 1.

Krook, H. (1961). Acta Medica Scandinavica, 169, 713

Leventhal, B. G., Waldorf, D. S., and Talal, N. (1967). fournal of Clinical Investigation, 46, 1338.

McLenachan, J. (1956). Trunsactions of the Ophthalmological Society of the United Kingdom, 76, 413.

Mason, A. M. S., and Golding, P. L. (1970). British Medical fournal, 3, 143

Ropes, M. W., Bennett, G. A., Cobb, S., Jacox, R., and Jessar, R. A. (1958). Bulletin on Rheumatic Diseases, 9,175 .

Sjögren, H. (1933). Acta Ophthalmologica, Suppl. No. 2, p. 1

Vanselow, N. A., Dodson, V. N., Angell, D. C., and Duff, I. F. (1963). Annals of Internal Medicine, 58, 124

Whaley, K., et al. (1970). Lancet, 1, 861.

\title{
Controlled Trial of Oxprenolol and Practolol in Hypertension
}

\author{
A. W. D. LEISHMAN, ${ }^{*}$ D.M., F.R.C.P. ; J. L. THIRKETTLE, $†$ M.B., M.R.C.P. ; B. R. ALLEN, $\ddagger$ M.B., CH.B., M.R.C.P.
} R. A. DIXON, $\subseteq$ B.SC.

British Medical fournal, 1970, 4, 342-344

\begin{abstract}
Summary : In controlled trials of the beta-adrenergic blocking drugs oxprenolol and practolol in hypertension both drugs were well tolerated without side effects and caused statistically significant non-postural reduction of blood pressure. In less than half the patients on either drug the reduction of blood pressure was clinically adequate. No attempt was made to compare the two drugs.
\end{abstract}

\section{Introduction}

It is established that beta-adrenergic blocking drugs have blood-pressure-lowering action, but opinions on the value of propranolol, the most widely used drug of this character, in the management of hypertension have varied. Paterson and Dollery (1966), Humphreys and Delvin (1968), and Richardson et al. (1967) were unenthusiastic, but Prichard and Gillam (1969) and Zacharias and Cowen (1970) reported favourably. The hypotensive action of propranolol may be due to reduction of sympathetic cardiac drive and cardiac output, there being no alteration in peripheral vascular resistance (Frolich et al., 1968). An advantage of this is that the drug causes neither postural nor exertional hypotension. In certain circumstances, however, propranolol may provoke heart failure and bronchospasm.

Both practolol (4-(2-hydroxy-3-isopropylaminopropoxy)acetanilide; Eraldin) and oxprenolol (1-(o-allyloxyphenoxy)-3isopropylamino-2-propanol hydrochloride; Trasicor) are beta-adrenergic blocking drugs which are relatively cardioselective, showing much less activity than propranolol in blocking other beta-receptors. Practolol does not show the quinidine-like effect of propranolol, but its other cardiac

- Consultant Physician, Royal Infirmary, Sheffield.

† Senior Medical Registrar, Royal Infirmary, Sheffield. (Now Consultant Physician, Crawley Hospital, Crawley, Sussex.

‡ Medical Registrar, Royal Infirmary, Sheffield.

Statistician, Department of Preventive Medicine, University of Sheffield. effects are similar, slowing the heart rate and reducing cardiac output, most pronounced on exercise. In its action on the heart, however, practolol appears to have about $40 \%$ of the potency of propranolol (Barrett et al., 1968). Oxprenolol appears to differ in one important respect from propranolol; for Wilson et al. (1968) showed that prolonged oral administration, though having varying effect on cardiac output, causes a noticeable increase in stroke volume, a property which might give it an advantage over propranolol.

This paper describes a small controlled trial of each of these drugs in the treatment of hypertensive patients.

\section{Methods}

Forty-eight patients wiere considered suitable for the trial, and after full explanation they agreed to take part; 24 were given oxprenolol and 24 received practolol. Allocation to either drug was by random selection. All had benign essential hypertension previously untreated. Patients with diastolic pressure exceeding $124 \mathrm{~mm} . \mathrm{Hg}$, blood urea higher than $50 \mathrm{mg} . / 100 \mathrm{ml}$., heart failure, or chronic respiratory disease were not included. The blood urea, white blood count, aspartate aminotransferase, alanine aminotransferase, and airways resistance $\left(\mathrm{FEV}_{1} / \mathrm{FVC} \times 100\right)$ were recorded at the start of the trial and immediately before the double-blind phase.

Initially, patients were admitted to the ward and kep under observation without treatment until the blood pressure reached a steady level. At this point a single test dose of the drug $(10 \mathrm{mg}$. of oxprenolol or $50 \mathrm{mg}$. of practolol) was given to exclude any untoward effect. If this was tolerated the patients were started on the respective drugs, given three times daily.

Oxprenolol was supplied in 20-mg. tablets. The starting dose was $20 \mathrm{mg}$. three times daily, and this was increased on alternate days by $20 \mathrm{mg}$. (all three doses) until the diastolic blood pressure was controlled or the previously agreed maxi- 
mum of $140 \mathrm{mg}$. three times daily had been reached. Practolol was available in 50-mg. and $200-\mathrm{mg}$. tablets. Dosage began at $50 \mathrm{mg}$. three times daily and was similarly increased until the blood pressure was controlled or the maximum accepted dosage of $600 \mathrm{mg}$. three times daily had been reached. Blood pressure was taken in lying and standing positions, a London School of Hygiene and Tropical Medicine sphygmomanometer being used to reduce observer bias and digital preference (Rose et al., 1964). Blood pressure control was considered satisfactory when the diastolic pressure (lying or standing) was below $100 \mathrm{~mm} . \mathrm{Hg}$.

After their discharge from the ward the patients' blood pressure was recorded at weekly intervals in the outpatient department, the dose being adjusted whenever necessary. The blood pressure was always measured by one observer and the treatment prescribed by another. When the blood pressure appeared to be adequately controlled or the daily dose of the drug was at the agreed maximum, patients entered a doubleblind phase of the trial with a cross-over, during which for periods each of four weeks, they received, either active drug or placebo allocated at random. It was agreed that, at the discretion of the observer, patients could be withdrawn from the trial at any stage if their blood pressure was obviously uncontrolled and readings were unsuitably high.

Tablet counts were made at each outpatient attendance, and from these it seems likely that the dose prescribed was taken on average with at least $90 \%$ accuracy.

\section{Results}

Oxprenolol.-Nineteen patients completed the trial; five were withdrawn on account of inadequate control, the diastolic pressure of the excluded patients being persistently above $120 \mathrm{~mm} . \mathrm{Hg}$ and none showing any lowering on maximum dose of the drug. The mean blood pressures recorded in each phase of the trial are shown in Table I, and the individual readings of diastolic pressure, lying and standing, during the double-blind phase of the trial are given in Table II. In the double-blind phase of the trial there was a statistically significant fall (using paired $t$ test) in both systolic and diastolic blood pressures, but the fall was less significant in the case of lying diastolic pressure than in the other three results. Three patients (Cases 1,10 , and 19) showed controlled levels of blood pressure in both lying and standing positions on placebo, but in each case blood pressure was lower while on the active drug. The mean daily dose of oxprenolol was $320 \mathrm{mg}$., with a range of $60-420 \mathrm{mg}$., 11 patients requiring the maximum dose. No side effects were noted other than moderate slowing of the heart, the mean rate on the drug being $75 /$ minute compared with $83 /$ minute on placebo, a difference which is significant $(P<0.01)$. There was no alteration in blood urea, blood count, enzyme levels, or airways resistance while taking the drug.

Practolol.-As with oxprenolol, 5 of the 24 patients starting

TABle I.-Mean Blood Pressures (mm.Hg) in Each Phase of the Trial

\begin{tabular}{|c|c|c|c|c|c|c|c|}
\hline & 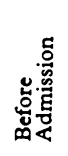 & 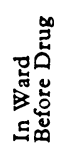 & 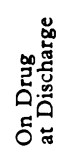 & 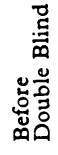 & \begin{tabular}{|l} 
Double \\
Placebo
\end{tabular} & Brugs & 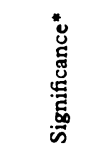 \\
\hline $\begin{array}{l}\text { Systolic standing .. } \\
\text { Systolic lying } \\
\text { Diastolic standing } \\
\text { Diastolic lying }\end{array}$ & $\begin{array}{l}186 \\
194 \\
115 \\
114\end{array}$ & $\begin{array}{l}175 \\
182 \\
110 \\
108\end{array}$ & $\begin{array}{c}\text { xprenolo } \\
159 \\
166 \\
99 \\
95\end{array}$ & $\begin{array}{r}153 \\
159 \\
101 \\
99\end{array}$ & $\begin{array}{l}165 \\
173 \\
106 \\
102\end{array}$ & $\begin{array}{r}151 \\
160 \\
99 \\
99\end{array}$ & $\begin{array}{l}P<0.001 \\
P<0.001 \\
P<0.001 \\
P<0.05\end{array}$ \\
\hline $\begin{array}{l}\text { Systolic standing .. } \\
\text { Systolic lying } \\
\text { Diastolic standing } \\
\text { Diastolic lying } \quad .\end{array}$ & $\begin{array}{l}194 \\
197 \\
116 \\
116\end{array}$ & $\begin{array}{l}182 \\
192 \\
113 \\
111\end{array}$ & $\begin{array}{l}\text { ractolol } \\
158 \\
169 \\
96 \\
96\end{array}$ & $\begin{array}{l}160 \\
169 \\
100 \\
100\end{array}$ & $\begin{array}{l}175 \\
183 \\
110 \\
107\end{array}$ & $\begin{array}{l}161 \\
171 \\
103 \\
101\end{array}$ & $\begin{array}{l}\mathbf{P}<\mathbf{0 . 0 0 1} \\
\mathrm{P}<\mathbf{0 . 0 1} \\
\mathbf{P}<\mathbf{0 . 0 5} \\
\mathrm{P}<\mathbf{0 . 0 5}\end{array}$ \\
\hline
\end{tabular}

-Figures relate to 19 out of 24 patients.
TABLE II.-Daily Dosage and Diastolic Blood Pressures (mm. $\mathrm{Hg}_{\mathrm{g}}$ Lying and Standing in 19 Cases Completing the Trial

\begin{tabular}{|c|c|c|c|c|c|c|c|}
\hline \multirow{2}{*}{$\begin{array}{l}\text { Case } \\
\text { No. }\end{array}$} & \multicolumn{3}{|c|}{ Standing } & \multicolumn{3}{|c|}{ Lying } & \multirow{2}{*}{$\begin{array}{c}\text { Daily } \\
\text { Dose } \\
\text { Oxprenolol } \\
\text { (mg.) }\end{array}$} \\
\hline & Placebo & Drug & $\begin{array}{l}\text { Change } \\
\text { in B.P. }\end{array}$ & Placebo & Drug & $\begin{array}{l}\text { Change } \\
\text { in B.P. }\end{array}$ & \\
\hline $\begin{aligned} 1 & \cdots \\
2 & \cdots \\
3 & \cdots \\
4 & \cdots \\
5 & \cdots \\
6 & \cdots \\
7 & \cdots \\
8 & \cdots \\
9 & \cdots \\
10 & \cdots \\
11 & \cdots \\
12 & \cdots \\
13 & \cdots \\
15 & \cdots \\
16 & \cdots \\
17 & \cdots \\
18 & \cdots \\
19 & \cdots\end{aligned}$ & $\begin{array}{r}90 \\
102 \\
109 \\
102 \\
102 \\
127 \\
115 \\
110 \\
110 \\
100 \\
101 \\
108 \\
104 \\
111 \\
106 \\
108 \\
106 \\
114 \\
90\end{array}$ & $\begin{array}{r}88 \\
97 \\
106 \\
100 \\
89 \\
113 \\
111 \\
99 \\
91 \\
85 \\
99 \\
92 \\
101 \\
101 \\
96 \\
111 \\
103 \\
110 \\
88\end{array}$ & $\begin{aligned} & \text { Oxp } \\
&= 2 \\
&= 5 \\
&= 3 \\
&= 2 \\
&-13 \\
&-14 \\
&=4 \\
&-11 \\
&-19 \\
&-15 \\
&=2 \\
&-16 \\
&=3 \\
&-10 \\
&-10 \\
&+ 3 \\
&= 3 \\
&= 4 \\
&- 2\end{aligned}$ & $\begin{array}{r}\text { nolol } \\
85 \\
106 \\
110 \\
103 \\
100 \\
126 \\
106 \\
100 \\
96 \\
98 \\
103 \\
95 \\
109 \\
105 \\
101 \\
95 \\
100 \\
106 \\
89\end{array}$ & $\begin{array}{r}82 \\
93 \\
107 \\
102 \\
92 \\
126 \\
112 \\
102 \\
82 \\
86 \\
96 \\
92 \\
110 \\
97 \\
103 \\
104 \\
94 \\
105 \\
88\end{array}$ & $\begin{array}{l}=3 \\
=13 \\
=3 \\
=1 \\
=8 \\
0 \\
+6 \\
\pm 2 \\
=14 \\
=12 \\
=7 \\
=3 \\
+1 \\
\pm 8 \\
+2 \\
\pm 9 \\
\pm 6 \\
=1 \\
-1\end{array}$ & $\begin{array}{r}120 \\
420 \\
420 \\
420 \\
60 \\
420 \\
360 \\
420 \\
120 \\
300 \\
360 \\
240 \\
420 \\
420 \\
420 \\
420 \\
420 \\
420 \\
60\end{array}$ \\
\hline $\begin{aligned} 1 & \cdots \\
2 & \cdots \\
3 & \cdots \\
4 & \cdots \\
5 & \cdots \\
6 & \cdots \\
7 & \cdots \\
8 & \cdots \\
9 & \cdots \\
10 & \cdots \\
11 & \cdots \\
12 & \cdots \\
13 & \cdots \\
14 & \cdots \\
16 & \cdots \\
17 & \cdots \\
18 & \cdots \\
19 & \end{aligned}$ & $\begin{array}{r}108 \\
84 \\
111 \\
113 \\
97 \\
102 \\
109 \\
94 \\
128 \\
113 \\
90 \\
116 \\
119 \\
101 \\
114 \\
115 \\
133 \\
107 \\
126\end{array}$ & $\begin{array}{r}102 \\
93 \\
95 \\
103 \\
81 \\
105 \\
101 \\
92 \\
135 \\
118 \\
86 \\
106 \\
121 \\
90 \\
96 \\
104 \\
118 \\
95 \\
113\end{array}$ & $\begin{aligned} & \text { Pra } \\
&- 6 \\
&+ 9 \\
&-16 \\
&-10 \\
&-16 \\
&+3 \\
&=8 \\
&-2 \\
&+7 \\
&+5 \\
&+4 \\
&-10 \\
&+2 \\
&-11 \\
&-18 \\
&-11 \\
&-15 \\
&-12 \\
&-13\end{aligned}$ & $\begin{array}{r}\text { colol } \\
105 \\
76 \\
103 \\
105 \\
92 \\
99 \\
102 \\
94 \\
122 \\
114 \\
91 \\
114 \\
120 \\
100 \\
111 \\
116 \\
125 \\
109 \\
136\end{array}$ & $\begin{array}{r}95 \\
86 \\
92 \\
103 \\
84 \\
113 \\
95 \\
76 \\
131 \\
121 \\
91 \\
97 \\
115 \\
98 \\
96 \\
105 \\
113 \\
91 \\
112\end{array}$ & $\begin{array}{r}-10 \\
+10 \\
-11 \\
=2 \\
-8 \\
+14 \\
-77 \\
-18 \\
+9 \\
+7 \\
0 \\
-17 \\
=5 \\
-12 \\
-15 \\
-11 \\
-12 \\
-18 \\
-24\end{array}$ & $\begin{array}{r}450 \\
150 \\
1,800 \\
1,200 \\
150 \\
1,800 \\
1,800 \\
300 \\
1,800 \\
1,800 \\
300 \\
1,800 \\
1,200 \\
600 \\
1,200 \\
1,800 \\
600 \\
300 \\
1,800\end{array}$ \\
\hline
\end{tabular}

the trial had to be eliminated because their blood pressure was uncontrolled despite maximal doses of practolol. The mean blood pressures of the remaining 19 patients are shown in Table $I$ and the individual records of diastolic pressure during the double-blind stage in Table II. Statistical analysis of the results (using paired $t$ test) shows that the drug has a significant blood-pressure-lowering effect. Four patients (Cases 2, 5, 8, and 11) maintained low diastolic readings on placebo but Cases 5, 8, and 11 had a further fall of blood pressure while on the active drug. Case 2 had very low blood pressures on the placebo. He was initially only mildly hypertensive and in retrospect should not have been included in the trial. Practolol, like oxprenolol, caused slowing of the heart, the mean rate on the drug being $76 /$ minute compared with $84 /$ minute on placebo $(P<0.001)$. Side effects were minimal, only three patients complaining of constipation. The blood count, blood urea, enzyme level, and airways resistance did not change during treatment with practolol. The average daily dose of practolol was $1,097 \mathrm{mg}$., ranging from 150 to $1,800 \mathrm{mg}$., eight patients taking the maximum dose.

\section{Conclusions}

Evidently both oxprenolol and practolol reduce blood pressure in both lying and standing positions, and statistical analysis confirms this. In the case of practolol this has been noted during trials of the drug in angina (Sandler and Clayton, 1970; George et al., 1970). As with other antihypertensive drugs, the blood-pressure-lowering effect was inconsistent, but it was a little disappointing that less than half our cases on either drug achieved the relatively modest standard of blood pressure reduction regarded as effective.

Both drugs were well tolerated and there were no side effects, but within the range of dosage used they have not appeared to show great potential as antihypertensive agents, and subsequent to the trial all but two of the patients have been placed on alternative treatment.

We are indebted to Professor J. Knowelden for helpful advice; to Dr. R. K. Rondel, of Ciba Laboratories, for supplies of Trasicor; and to Dr. M. Jewell, of I.C.I., for supplies of Eraldin. 
REFERENCES

Barrett, A. M., Crowther, A. F., Dunlop, D., Shanks, R. G., and Smith, L. H. (1968). Naunyn-Schmiedeberg's Archiv für Pharmakologie und experimentelle Pathologie, $259,152$.

Frolich, E. D., Tarazi, R. C., Dustan, H. P., and Page, I. H. (1968). Circulation, 37, 417 .

George, C. F., Nagle, R. E., and Pentecost, B. L. (1970). British Medical fournal, 2, 402.

Humphreys, G. S., and Delvin, D. G. (1968). British Medical fournal, 2, 601.

Paterson, J. W., and Dollery, C. T. (1966). Lancet, 2, 1148.
Prichard, B. N. C., and Gillam, P. M. S. (1969). British Medical fournal, $1,7$.

Richardson, D. W., Freund, J., Gear, A. S., Mauck, H. P., jun., and Preston L. W. (1967). Circulation, 37, 534.

Rose, G. A., Holland, W. W., and Crowley, E. A. (1964). Lancet, 1, 296.

Sandler, G., and Clayton, G. A. (1970). British Medical fournal, 1, 296.

Wilson, D. F., Watson, O. F., Peel, S. S., Langley, R. B., and Turner A. S. (1968). New Zealand Medical fournal, 68, 145.

Zacharias, F. J., and Cowen, K. J. (1970). British Medical fournal, 1, 471.

\section{Preliminary Communications}

\section{Inhibition of Metastatic Spread by I.C.R.F. 159: Selective Deletion of a Malignant Characteristic}

British Medical fournal, 1970, 4, 344-346

\begin{abstract}
Summary: Treatment with I.C.R.F. 159 completely $\checkmark$ inhibited metastasis formation in mice implanted with Lewis lung carcinoma at doses having little influence on the rate of growth of the primary implant. This inhibition was due to the effect of I.C.R.F. 159 on the development of blood vessels of the invading margins of the primary tumour. So far as is known, this is the first time a drug has induced a specific loss of the malignant characteristic of blood-borne tumour cell dissemination.
\end{abstract}

\section{INTRODUCTION}

Few attempts have been made to find new substances which prevent tumour cell dissemination (Handler, Sarris, and Wills, 1964; Donelli, Rosso, and Garattini, 1969; Rosso, Donelli, Franchi, and Garattini, 1969). This may largely be due to the difficulty of finding suitable experimental models, and most other workers have therefore bypassed the problem by injecting tumour cells intravenously. This expedient is not entirely satisfactory, since important early stages in the process of metastatic spread are thereby also bypassed.

We have used the Lewis lung carcinoma (3LL) in $\mathrm{C}_{57} \mathrm{Bl}$ mice as our test system because it has the important property, when implanted in the flank, of metastasizing spontaneously to the lungs (Ketcham, Wexler, and Minton, 1966; Wexler, Ryan, and Ketcham, 1969) and in our experience consistently, regularly, and predictably in all inoculated animals. Thus a precise experimental baseline is established of the organ invaded (the lungs) and of the time of invasion (nine days, microscopically). With this system a new cytostatic agent, ( \pm )-1,2-bis(3,5-dioxopiperazin-l-yl) propane, I.C.R.F. 159 (Creighton, Hellmann, and Whitecross, 1969; Hellmann, Newton, Whitmore, Hanham, and Bond, 1969; Hellmann and Field, 1970; Sharpe, Field, and Hellmann, 1970), has controlled metastasis formation at doses having no overt influence on the growth of the primary tumour (Hellmann and Burrage, 1969). The mechanism of this inhibition has now been examined more closely, a preliminary account of the work being given elsewhere (Burrage, Hellmann, and Salsbury, 1970).

Essentially the experiments were designed to compare the microscopical changes in blood, lungs, and primary tumour after 3LL implantation in control and I.C.R.F. 159-treated animals to see if it was possib'e to discover morphological reasons for the inhibition of merastatic spread produced by I.C.R.F. 159. Cyclophosphamide was used for comparison.

\section{Materials AND MethodS}

Effect on Primary Tumour Growth.-All mice used were $\mathrm{C}_{5 i} \mathrm{~B} 1$ females of about $20 \mathrm{~g}$. weight. All tumour inoculations were made subcutaneously in the flank. Methods of transplanting the tumour were those used routinely in the department of cancer chemotherapy of the I.C.R.F. (Hellmann, Marshall, and Stayt, 1967). Test mice received I.C.R.F. $159,30 \mathrm{mg} . / \mathrm{kg}$., suspended in carboxymethyl cellulose solution intraperitoneally and the control mice received carboxymethyl cellulose aione intraperitoneally. Tumours were removed and examined macroscopically, and the test/control value was obtained by dividing the mean weight of test tumours by the mean weight of control tumours. The schedule of injections and the results are given in Table I.

TABLE I.-Effect of I.C.R.F. 159 on Primary $3 L L$ Tumour Growth

\begin{tabular}{|c|c|c|c|}
\hline $\begin{array}{l}\text { Days After Implantation } \\
\text { on which Injections Given }\end{array}$ & $\begin{array}{c}\text { Days After } \\
\text { Implantation on } \\
\text { which Primary } \\
\text { Tumour } \\
\text { Removed }\end{array}$ & $\begin{array}{c}\text { Mean Weight (g.) } \\
\text { Test/Control } \\
\text { ( } 5 \text { mice in } \\
\text { each group) }\end{array}$ & $\begin{array}{l}\text { Test/Control } \\
\text { Value }\end{array}$ \\
\hline \multirow{3}{*}{$\left.\begin{array}{l}1,2,3,4 \\
1,2,3,4 \quad \ldots\end{array} \begin{array}{l}1,2,3,4,7,8,9 \\
1,2,3,4,7,8,9,10,11 \\
1,2,3,4,7,8,9,10,11,14, \\
15,2,3,4,7,8,9,10,11,14, \\
15,16\end{array}\right\}$} & $\begin{array}{r}4 \\
7 \\
10 \\
14\end{array}$ & $\begin{array}{l}0.056 / 0 \cdot 075 \\
0.160 / 0 \cdot 256 \\
0.377 / 0.625 \\
1.120 / 1 \cdot 714\end{array}$ & $\begin{array}{l}0.73 \\
0.62 \\
0.60 \\
0.65\end{array}$ \\
\hline & 16 & $1 \cdot 411 / 1 \cdot 780$ & 0.80 \\
\hline & 19 & $1 \cdot 780 / 2 \cdot 343$ & $0 \cdot 76$ \\
\hline
\end{tabular}

Lungs and Blood in Mice Implanted with Tumour.Tumour implantation and treatment were as described above, and are summarized in Table II. The lungs of these mice were removed, fixed, and individual lobes separated. After dehydration and embedding, a section $(8 \mu \mathrm{m}$.) was cut across the centre of each lobe. Pooled blood from the mice was collected into sodium edetate (Sequestrene) and averaged 4

TABLE II.-Experimental Protocol to Show Effect of I.C.R.F. 159 on Pulmonary Metastases and Circulating $3 L L$ Cells in Mice Implanted With $3 L$ Tumour. Six Mice in Each Group

Mice Implanted with 3LL Tumour

\begin{tabular}{ll|ll|l} 
Days After Implantation on which I.C.R.F. \\
159 Given
\end{tabular}

ml. from each group of six. A nucleated cell concentrate was obtained by double centrifugation. Films were made of the whole of the nucleated cell layer, fixed in methyl alcohol, and stained with May-Grünwald-Giemsa.

Histological Examination.-Details of the experiment are given in Table III. Tumour implantation and treatment were 